bond angles are (I) $115 \cdot 5$ (2)-126.4 (2), (II) 120.6 (3)$121.6(3)$, and (III) $115.3(3)-126.4(4)^{\circ}$, suggesting that the lone-pair lobes of the $\mathrm{N}$ atoms are directed approximately towards the $\mathrm{Ag}^{+}$ions. In (I) and (II), the complex cations exhibit simple and straightforward coordination geometries through the two $\mathrm{N}$ atoms of the diazanaphthalene molecules, and are consistent with SER spectra. The structure of (III) is also in harmony with the expectation from the SERS study that phthalazine displays two kinds of adsorptions, unidentate and bridged, on a silver surface, depending upon the electrode potentials.

References

Hamilton, W. C. (1959). Acta Cryst. 12, 609-610.
International Tables for X-ray Crystallography (1974). Vol. IV. Birmingham: Kynoch Press. (Present distributor Kluwer Academic Publishers, Dordrecht.)

JoHNSON, C. K. (1965). ORTEP. Report ORNL-3794. Oak Ridge National Laboratory, Tennessee, USA.

main, P., Hull, S. E., Lessinger, L., Germain, G., DeclercQ, J.-P. \& Woolfson, M. M. (1978). MULTAN78. A System of Computer Programs for the Automatic Solution of Crystal Structures from $X$-ray Diffraction Data. Univs. of York, England, and Louvain, Belgium.

Rhodin, T. N. \& ERTL, G. (1979). The Nature of the Surface Chemical Bond. Oxford: North-Holland.

SAKURAI, T. \& KoBAYASHI, K. (1979). Rikagaku Kenkyusho Hokoku, 55, 69-77.

Takahashi, M., Furukawa, H., Fujita, M. \& Ito, M. (1987). J. Phys. Chem. 91, 5940-5943.

Takahashi, M., SaKal, Y., Fujita, M. \& Ito, M. (1986). Surf. Sci. 176, 351-366.

Vranka, R. G. \& Amma, E. L. (1966). Inorg. Chem. 5, $1020-1025$.

Acta Cryst. (1989). C45, 890-892

\title{
Structure of a Pentacoordinate Complex of Bis(diphenyldithiophosphinato)cobalt(II) with 3-Methylpyridine
}

\author{
By Kalyan Das, U. C. Sinha* and R. N. Mukherjee \\ Department of Physics and Department of Chemistry, Indian Institute of Technology, Bombay-400076, India
}

AND RAKESH BOHRA

Department of Chemistry, University of Rajasthan, Jaipur-302016, India

(Received 11 October 1988; accepted 7 December 1988)

\begin{abstract}
Bis(diphenyldithiophosphinato)(3-methylpyridine)cobalt(II), $\left[\mathrm{Co}\left(\mathrm{C}_{6} \mathrm{H}_{7} \mathrm{~N}\right)\left\{\mathrm{P}\left(\mathrm{C}_{6} \mathrm{H}_{5}\right)_{2} \mathrm{~S}_{2}\right\}_{2}\right], M_{r}=$ 650.69, orthorhombic, Fdd2, $a=23.964(4), \quad b=$ 28.274 (7), $c=9.209$ (5) $\AA, V=6240.42 \AA^{3}, Z=8$, $D_{m}=1.33$ (by flotation in aqueous $\mathrm{Zn}$ solution), $D_{x}=1.385 \mathrm{Mg} \mathrm{m}^{-3}, \quad \lambda(\mathrm{Mo} \mathrm{K \alpha})=0.71069 \AA, \quad \mu=$ $0.87 \mathrm{~mm}^{-1}, F(000)=2664.00, T=295 \mathrm{~K}$, final $R$ $=0.029$ for 1179 reflections. The coordination polyhedron around the $\mathrm{Co}^{\mathrm{II}}$ ion is a distorted trigonal bipyramid. The $\mathrm{S}$ atoms in the bidentate diphenyldithiophosphinato (dtpi) ligand are coordinated to the metal in both axial and equatorial directions.
\end{abstract}

Introduction. Dithio acid ions such as dtpi are able to form four-membered chelates with $3 d$ transition metals. The Co atom has an almost tetrahedral coordination environment in $\mid \mathrm{Co}(\mathrm{dtpi})_{2} \mathrm{l}$, so the introduction of another ligand severely affects the coordination geometry. The pentacoordinated complexes $\left[\mathrm{Co}(\mathrm{dtpi})_{2^{-}}\right.$

\footnotetext{
* To whom correspondence should be addressed at Department of Physics.
}

$(L)$ ], where $L$ represents 2-, 3- and 4-methylpyridine, 2-aminopyridine, quinoline and isoquinoline, are found to be quite stable in the solid state. The $1: 1$ adduct with a monodentate axial ligand like 2-, 3- or 4-methylpyridine can have a trigonal bipyramidal or a square pyramidal configuration. In order to find the exact coordination geometry around the $\mathrm{Co}^{11}$ ion, X-ray diffraction studies of the 3-methylpyridine derivative were carried out. The 2-methylpyridine adduct is isomorphous to the 3-methylpyridine adduct (Patel \& Sinha, 1977) but owing to steric effects the latter is found to be more stable.

Experimental. The heterocyclic amine was added in excess to a solution of cobalt chloride hexahydrate in methanol. To this blue solution the calculated amount of sulfur ligand (dtpiH) was added and the required complex separated almost immediately. It was crystallized from a chloroform-methanol mixture (Mukherjee, Venkateshan \& Zingde, 1974).

Blue crystal of dimensions $0.2 \times 0.2 \times 0.2 \mathrm{~mm}$; Enraf-Nonius CAD-4 diffractometer, graphite-mono- 
Table 1. Atomic coordinates $\left(\times 10^{5}\right.$ for $\mathrm{S}$ and $\mathrm{P}$ atoms; $\times 10^{4}$ for other non- $\mathrm{H}$ atoms) and equivalent isotropic temperature factors $U_{c q}\left(\AA^{2} \times 10^{3}\right)$ with e.s.d.'s in parentheses

\begin{tabular}{|c|c|c|c|c|}
\hline & $U_{\mathrm{c}}$ & ${ }_{i}{ }_{i} U_{i j} a$ & $\left(\mathbf{a}_{i} \cdot \mathbf{a}_{j}\right)$ & \\
\hline & $x$ & $y$ & $z$ & $U_{\text {(a) }}$ \\
\hline $\mathrm{Co}^{*}$ & $2500 \dagger$ & $2500 \dagger$ & $0 \dagger$ & $53(1)$ \\
\hline $\mathrm{N}^{*}$ & $2500 \ddagger$ & $2500 \ddagger$ & $-2147(8)$ & $56(6)$ \\
\hline$S(1)$ & 16557 (5) & $19133(5)$ & $1004(26)$ & 59 (1) \\
\hline$S(2)$ & $29554(5)$ & $18886(5)$ & $12230(23)$ & 55 (1) \\
\hline $\mathrm{P}$ & $22168(5)$ & $15423(5)$ & $11973(21)$ & 46 (1) \\
\hline$C(3)$ & $2053(3)$ & $2634(3)$ & $-2903(8)$ & 71 (7) \\
\hline$C(4)$ & 2024 (4) & $2646(3)$ & $-4396(8)$ & $86(8)$ \\
\hline$C(5)^{*}$ & $2500 \ddagger$ & $2500 \ddagger$ & $-5139(12)$ & $90(10)$ \\
\hline $\mathrm{C}(6)$ & $1460(8)$ & $2792(5)$ & $-5066(16)$ & 95 (12) \\
\hline C(II) & $2318(2)$ & $958(2)$ & $435(6)$ & $48(5)$ \\
\hline C(12) & $1897(3)$ & 744 (2) & $-307(10)$ & $88(8)$ \\
\hline$C(13)$ & $1976(4)$ & 299 (3) & $-883(12)$ & $114(9)$ \\
\hline $\mathrm{C}(14)$ & $2463(4)$ & $67(2)$ & $-725(10)$ & $102(9)$ \\
\hline$C(15)$ & $2876(3)$ & $277(3)$ & 41 (13) & $102(9)$ \\
\hline$C(16)$ & $2820(3)$ & 729 (2) & $605(9)$ & $76(7)$ \\
\hline$C(21)$ & 1991 (3) & $1437(2)$ & 3052 (7) & $60(6)$ \\
\hline$C(22)$ & $2358(4)$ & $1266(3)$ & 4061 (8) & $83(8)$ \\
\hline $\mathrm{C}(23)$ & $2170(5)$ & $1188(4)$ & $5483(9)$ & $108(10)$ \\
\hline$C(24)$ & $1626(7)$ & $1268(5)$ & 5836 (11) & 137 (11) \\
\hline$C(25)$ & 1221 (4) & $1435(5)$ & 4847 (12) & 141 (11) \\
\hline$C(26)$ & $1438(4)$ & $1523(4)$ & $3464(10)$ & $104(9)$ \\
\hline & & atio & $\begin{array}{l}\mathrm{r} \text { is } 0.5 \text {. } \\
\text { rigin. }\end{array}$ & \\
\hline
\end{tabular}

Table 2. Selected bond distances $(\AA)$ and bond angles $\left({ }^{\circ}\right)$ with e.s.d.'s in parentheses

\begin{tabular}{|c|c|c|c|}
\hline $\mathrm{N}-\mathrm{Co}$ & $1.978(7)$ & $P-S(1)$ & $1.982(2)$ \\
\hline $\mathrm{S}(1)-\mathrm{Co}$ & $2.618(1)$ & $\mathrm{P}-\mathrm{S}(2)$ & $2.023(2)$ \\
\hline$S(2)-C_{0}$ & $2.334(2)$ & $C(11)-P$ & $1.811(5)$ \\
\hline $\mathrm{C}(3)-\mathrm{N}$ & $1.333(8)$ & $C(21)-P$ & $1.817(7)$ \\
\hline$C(6)-C(4)$ & $1.543(19)$ & & \\
\hline $\mathrm{S}(1)-\mathrm{Co}-\mathrm{N}$ & $92.0(1)$ & $C(21)-P-S(2)$ & $109 \cdot 2(2)$ \\
\hline $\mathrm{S}(2)-\mathrm{Co}-\mathrm{N}$ & $118.9(0)$ & $\mathrm{C}(21)-\mathrm{P}-\mathrm{C}(11)$ & $104.7(3)$ \\
\hline$S(2)-\mathrm{Co}-\mathrm{S}(1)$ & $82.8(0)$ & $\mathrm{C}(4)-\mathrm{C}(3)-\mathrm{N}$ & $124.6(8)$ \\
\hline $\mathrm{C}(3)-\mathrm{N}-\mathrm{Co}$ & $121 \cdot 5(4)$ & $C(6)-C(4)-C(3)$ & $116 \cdot 7(9)$ \\
\hline $\mathrm{P}-\mathrm{S}(1)-\mathrm{Co}$ & 80.2 (1) & $\mathrm{C}(6)-\mathrm{C}(4)-\mathrm{C}(5)$ & $126.9(9)$ \\
\hline $\mathrm{P}-\mathrm{S}(2)-\mathrm{Co}$ & 86.8 (1) & $C(16)-C(11)-P$ & $120 \cdot 1$ (4) \\
\hline $\mathrm{S}(2)-\mathrm{P}-\mathrm{S}(1)$ & 110.1 (1) & $\mathrm{C}(12)-\mathrm{C}(11)-\mathrm{P}$ & $120 \cdot 2(4)$ \\
\hline $\mathrm{C}(11)-\mathrm{P}-\mathrm{S}(1)$ & $112.0(2)$ & $\mathrm{C}(22)-\mathrm{C}(21)-\mathrm{P}$ & $120.4(5)$ \\
\hline $\mathrm{C}(11)-\mathrm{P}-\mathrm{S}(2)$ & $109.2(2)$ & $\mathrm{C}(26)-\mathrm{C}(21)-\mathrm{P}$ & $120.5(6)$ \\
\hline $\mathrm{C}(21)-\mathrm{P}-\mathrm{S}(1)$ & $111.4(2)$ & & \\
\hline
\end{tabular}

chromated Mo $K \alpha$ radiation; space group was determined from Weissenberg photographs; lattice parameters refined from 25 reflections in the range $7<$ $\theta<11^{\circ} ;$ two standard reflections $(8 \overline{8} \overline{2}$ and $10,0, \overline{2})$ measured every $1800 \mathrm{~s}$ indicated no significant intensity variation; $\omega / 2 \theta$ scan, resolution $d=0.84 \AA ; 1936$ reflections measured in the range $2 \leq \theta \leq 25^{\circ}, 0 \leq$ $h \leq 28,0 \leq k \leq 33,0 \leq l \leq 10$, symmetry equivalent reflections were averaged, $R_{\mathrm{itt}}=0 \cdot 0$. Total 1221 observed reflections with $F>3 \cdot 0 \sigma(F)$ used for structure determination; $\mathrm{Lp}$ correction, no absorption or extinction correction. The structure was solved by Patterson and Fourier methods. Co, N and C(5) atoms occupied special positions on twofold axis, i.e. the $z$ axis. All the non-H atoms were refined using anisotropic thermal parameters, with constraints on positional parameters and anisotropic temperature factors $\left(U_{13}, U_{23}\right)$ for those atoms occupying special positions (Peterse \& Palm, 1966). All the $\mathrm{H}$ atoms except one [connected to $\mathrm{C}(4)$ ] were located from difference Fourier map and refined isotropically. The refinement of the structure was by a least-squares method based on $F$ values. In final calculations, reflections with $F<$ $5.0 \sigma(F)$ and $F_{c}>F_{o}$ with $\left(F_{o}-F_{c}\right) / \sigma(|F|)>3.0$ were omitted. $R_{\text {rinal }}=0.029$, unit weights (weighting scheme with $w=k /\left[\sigma^{2}(F)+\operatorname{abs}(g) F^{2}\right]$ was applied but the value of $g$ became zero whereas $k$ converged to 1$\}$, $w R=0.033, \quad(\Delta / \sigma)_{\max }=0.134$ with mean $(\Delta / \sigma)=$ $-0.014,(\Delta \rho)_{\max }=0.447 \mathrm{e} \AA^{-3}$ near cation, $(\Delta \rho)_{\min }$ $=-0.358 \mathrm{e} \AA^{-3}$.

Program SHELXS84 (Sheldrick, 1985) for structure determination, SHELX76 (Sheldrick, 1976) for leastsquares refinements, PLUTO78 (Motherwell \& Clegg, 1978) for plotting molecular structure and crystal packing, computer CYBER-180. Atomic scattering factors for $\mathrm{Co}^{11}$ are taken from International Tables for $X$-ray Crystallography (1974) and those for other atoms from $S H E L X 76$.

Discussion. The atomic coordinates of the non- $\mathrm{H}$ atoms are given in Table 1 , bond lengths and bond angles in Table 2.* Fig. 1 represents the stereochemical arrangement of the complex.

* Lists of structure factors, anisotropic thermal parameters, $\mathrm{H}$-atom parameters, least-squares planes and all bond lengths and angles not involving $\mathrm{H}$ have been deposited with the British Library Document Supply Centre as Supplementary Publication No. SUP 51671 (10 pp.). Copies may be obtained through The Executive Secretary, International Union of Crystallography, 5 Abbey Square, Chester CH1 2HU, England.

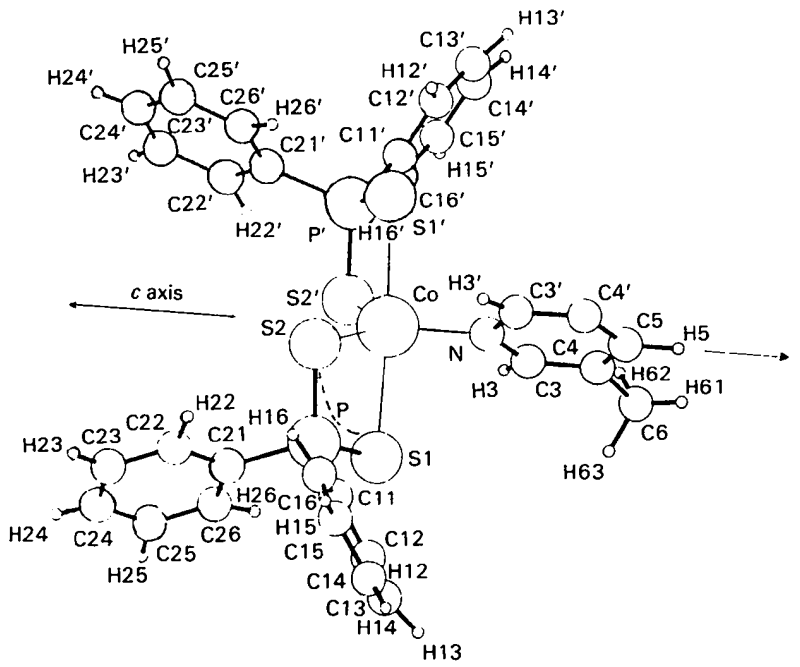

Fig. 1. General view of the molecule with atomic numbering. 
The molecule is placed on a twofold axis along the crystallographic $c$ axis. But the methyl group attached at position 3 of the pyridine ring violates the twofold symmetry of the molecule. As a consequence, the $\mathrm{CH}_{3}$ group is disordered between $\mathrm{C}(4)$ and $\mathrm{C}\left(4^{\prime}\right)$. The $\mathrm{Co}$, $\mathrm{N}, \mathrm{C}(5)$ and $\mathrm{H}(5)$ atoms are situated on the twofold axis. The coordination geometry around $\mathrm{Co}^{11}$ is a distorted trigonal bipyramid (Fig. 2), the equatorial plane of which contains $\mathrm{Co}, \mathrm{N}, \mathrm{S}(2)$ and $\mathrm{S}\left(2^{\prime}\right)$ atoms. The bond angles around the $\mathrm{Co}$ atom in the equatorial plane are close to $120^{\circ}\left[\mathrm{S}(2)-\mathrm{Co}-\mathrm{S}\left(2^{\prime}\right) 122 \cdot 3(1)\right.$ and $\left.\mathrm{N}-\mathrm{Co}-\mathrm{S}(2) \quad 118.92(7)^{\circ}\right]$. The out-of-plane $\mathrm{S}(1)$ and

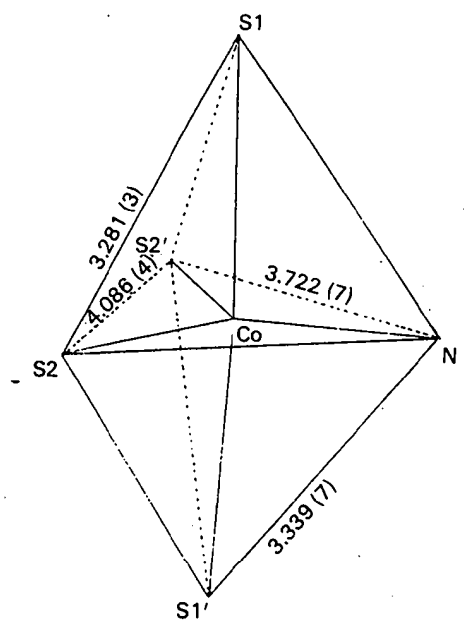

Fig. 2. Coordination polyhedron around the $\mathrm{Co}^{\mathrm{II}}$ ion.

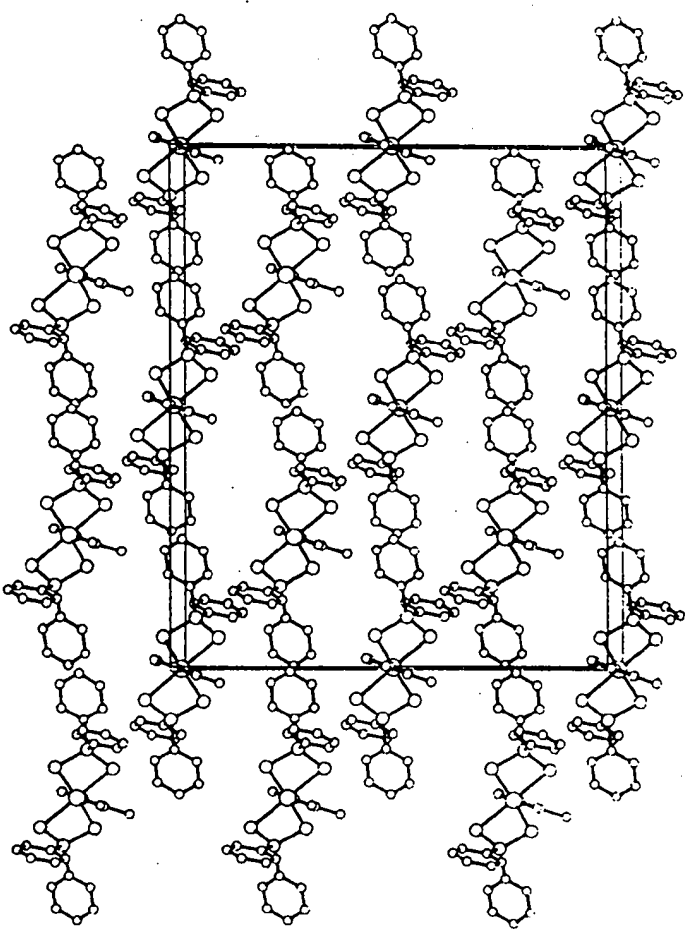

Fig. 3. Unit-cell packing diagram.
$S\left(1^{\prime}\right)$ atoms are almost collinear with the central metal atom $\left[\mathrm{S}(1)-\mathrm{Co}-\mathrm{S}\left(1^{\prime}\right) 176 \cdot 1(2)^{\circ}\right]$. The bond distances between the out-of-plane $\mathrm{S}$ atoms and $\mathrm{Co}[\mathrm{Co}-\mathrm{S}(1)$ $2.618(1) \AA]$ are significantly longer than the in-plane distances $[\mathrm{Co}-\mathrm{S}(2) 2.334(2) \AA]$. The average $\mathrm{P}-\mathrm{S}$ bond distance is 2.003 (2) $\AA$, compared with the usual $\mathrm{P}=\mathrm{S}(1.92 \AA)$ and $\mathrm{P}-\mathrm{S}$ distances $(2.10 \AA)$ (Wells, 1975). This indicates that the $P=S$ character in the dtpi ligand is delocalized in this system with the $\mathrm{P}-\mathrm{S}(1)$ bond slightly favoured $[\mathrm{P}-\mathrm{S}(1) 1.982(2) ; \mathrm{P}-\mathrm{S}(2)$ 2.023 (2) Å] (Shimoi, Ouchi, Uehiro \& Yoshino, 1982). $\mathrm{P}-\mathrm{C}$ distances are almost equal with average 1.814 (6) $\AA$. The least-squares plane fitted to $S(1), S(2)$ and $\mathrm{P}$ atoms is at an angle of $88.8(3)^{\circ}$ with the equatorial plane and $65.1(5)^{\circ}$ with the plane containing $S\left(1^{\prime}\right), S\left(2^{\prime}\right)$ and $P^{\prime}$. Both the phenyl rings in the dtpi ligand are almost planar [with maximum deviation of -0.02 (1) $\AA$ from their mean planes] and the angle between them is $75.9(8)^{\circ}$. These two planes are at angles of $51.7(7)$ and $54.1(6)^{\circ}$, respectively, with the mean plane passing through the atoms $\mathrm{P}, \mathrm{S}(1)$ and $\mathrm{S}(2)$. The least-squares plane fitted to the atoms $\mathrm{N}, \mathrm{C}(3)$, $\mathrm{C}(4), \mathrm{C}(5), \mathrm{C}\left(3^{\prime}\right)$ and $\mathrm{C}\left(4^{\prime}\right)$ [maximum deviation $\mathrm{C}(4)$ $-0.008(8) \AA]$ of the pyridine ring is at an angle of $38.2(5)^{\circ}$ with the equatorial plane passing through $\mathrm{Co}$, $\mathrm{N}, \mathrm{S}(1)$ and $\mathrm{S}\left(1^{\prime}\right)$. The methyl $\mathrm{C}$ atom deviates by 0.05 (1) $\AA$ from the mean plane passing through the pyridine ring.

Fig. 3 shows the crystal packing diagram. The minimum intermolecular distance is $3.582(8) \AA$. This is indicative of the presence of only van der Waals interactions and is in agreement with the electronic spectral studies (Mukherjee, Venkateshan \& Zingde, 1974).

The authors acknowledge the help from the Department of Chemistry, University of Rajasthan, Jaipur, for extending the CAD- 4 facility for intensity data.

\section{References}

International Tables for X-ray Crystallography (1974). Vol. IV, pp. 99, 149. Birmingham: Kynoch Press. (Present distributor Kluwer Academic Publishers, Dordrecht.)

Motherwell, W. D. S. \& ClegG, W. (1978). PLUTO78. Program for plotting molecular and crystal structures. Univ. of Cambridge, England.

Mukherjee, R. N., Venkateshan, M. S. \& Zingde, M. D. (1974). J. Inorg. Nucl. Chem. 36, 547-550.

PATEL, T. \& Sinha, U. C. (1977). Z. Kristallogr. 146, 325.

Peterse, W. J. A. M. \& Palm, J. H. (1966). Acta Cryst. 20. 147-150.

ShELdRICK, G. M. (1976). SHELX76. Program for crystal structure determination. Univ. of Cambridge, England.

SHELDRICK, G. M. (1985). SHELXS84. In Crystallographic Computing 3, edited by G. M. SHeldrick, C. KRüGER \&. R. GODDARD, pp. 175-189. Oxford: Clarendon Press.

Shimoi, M., Ouchi, A., Uehiro, T. \& Yoshino, Y. (1982). Bull. Chem. Soc. Jpn, 55, 2371-2377.

Wells, A. F. (1975). Structural Inorganic Chemistry, 4th ed. Oxford: Clarendon Press. 